\title{
The Effect of Palliative Care toward the Level of Anxiety and Pap Smear among Cervical Cancer Patients
}

\author{
Asrin $^{1}$, Siti Mulidah ${ }^{2}$, Welas Haryati ${ }^{3}$ \\ 1,2,3 Politeknik Kesehatan, Kemenkes Semarang, Jl. Tirto Agung Pedalangan, Banyumanik, Indonesia \\ *Corresponding Author: Asrin Politeknik Kesehatan, Kemenkes Semarang, Jl. Tirto Agung Pedalangan, \\ Banyumanik, Indonesia, Email: asrinakhmas@yahoo.com
}

Received : June 09, 2017

Accepted: June 19, 2017

Published: June 28, 2017

\begin{abstract}
Background: Cervix cancer is cancer attacking uterus in area of cervix uterus or neck uterus. It is the biggest number of women malignancy disease. Prevalence of cervical cancer in Indonesia is 4.3 per 1000 of populations. The highest prevalence is in Yogyakarta which is 9.6 per 1000 of populations. The recovery rate of cervical cancer from palliative stage is low making patients always suffer from physical and psychological problems that can cause anxiety.
\end{abstract}

The objective: This study was conducted to know the effect of palliative care toward the level of anxiety and Pap Smear for cervical cancer patients.

Method: The type of this study is quasi experimental with one group pre and post test design. The population were all 41 cervical cancer patients admitted in Margono Soekarjo Hospital, Purwokerto, Indonesia during 2016. The anxiety questionnaire was used to find out the level of anxiety and Wilcoxon test was applied to find the difference before and after palliative treatment.

Result: The levels of cervical cancer anxiety before and after palliative care in average are 27 and 20 indicating the decrease of 7 points, and statistical test confirms there is a significant effect of palliative care toward the level of anxiety $(p=0.000)$ and pap smear (0.003) for patients with cervical cancer

Conclusion: The palliative care can cause the decrease of anxiety and pap smear level for patients with cervical cancer.

Keywords: Palliative care, anxiety, pap smear, and cervix cancer.

\section{INTRODUCTION}

Cervical cancer is the third most numbered cancers in the world. Cervical cancer is also called "silent killer" because the development of this cancer is very difficult to detect. The journey from viral infection to cancer takes quite a long time, about 10-20 years. The World Health Organization (WHO) said the current cervical cancer is ranked among the most common cancers that cause deaths among women in the world. In Indonesia, every year more than 15,000 cases of cervical cancer are detected and every one hour a woman dies from this cancer. According to WHO, Indonesia is a country with the highest number of cervical cancer patients in the world.
According to data from the Ministry of Health of the Republic of Indonesia, the cervical cancer is found as many as 100 cases per 100 thousand inhabitants or 200 thousand cases each year. Cancer is the number 7 cause of death $(5.7 \%)$ and in 2011 the prevalence of cancer in Indonesia is 4.3 per 1000 population. The highest prevalence of cancer in Indonesia is reported in the Special Region of Yogyakarta Province which is 9.6 per 1000 inhabitants.

Palliative care is an approach that aims to improve the quality of life of patients and families who face problems related to lifethreatening disease through prevention and elimination, through early identification and orderly assessment and handling of pain and 
others related to physical, psychosocial and spiritual problems (KEPMENKES RI,2007)

This study aims to determine the effect of palliative care on the level of anxiety and pap smear cervical cancer patients. This way, it is expected to find a method to help reducing anxiety to increase patients' confidence in facing the disease process as well reducing anxiety of cervical cancer patients to improve the quality of life.

Types of palliative care activities include pain management, management of other physical complaints, nursing care, psychological support, social support, cultural and spiritual support, preparation support and support during the period of bereavement. Palliative care is done through inpatient, outpatient, and visits / home care (KEPMENKES RI, 2007).

In essence, palliative care is any form of medical treatment or treatment for a disease that focuses on the intensity of reducing symptoms of disease. Therefore, it can be concluded that the goals of psycho-oncology and palliative care run parallel to one another (Doyle, Hanks \& MacDonald, 2003).

The anxiety of patients with cervical cancer is an unclear and widespread concern associated with feelings of uncertainty and helplessness. This emotional state has no specific object (Stuart, 2006). Another anxiety according to Hawari (2001) is an affective disorder characterized by feelings of deep and continuing fear or concern, no disturbance in assessing reality, personality intact, behavior disturbance but still within normal limits. Hayati (2014) showed that anxiety levels in patients with stage III cervical cancer at a hospital in Bandung were $64.4 \%$ of respondents experiencing severe anxiety, $26.7 \%$ moderate anxiety, and $8.9 \%$ experienced mild anxiety.

\section{Materials ANd Methods}

This research uses Quasi experiment, using one group pre-post test design. This study subjects were observed twice before and after treatment of palliative care: psycho-education and social support. Anxiety levels were measured prior to psycho-education and social support as pre test and after the treatment of anxiety level assessment as post test.

This research was conducted for 3 months at Margono Soekarjo Hospital, Purwokerto and surrounding areas. Population is all cervical cancer patients in 2016. The no. of samples in this study were 41 out of 70 patients taken with consecutive sampling technique which is a type of non-probability sampling.

The dependent variables in this study are the level of anxiety and pap smear cervical cancer patients, while the independent variable in this research is palliative care. The instrument used was The Hamilton Anxiety Rating Scale Questionnaire (HARS), Psycho education guidelines, and cervical cancer leaflet. Data is analyzed with descriptive analysis to present the results in the form of frequency distribution. The influence of palliative care interventions (psychoeducation and social support) in decreasing anxiety levels of cervical cancer patients is calculated with Wilcoxon signed-rank test-a non-parametric statistical hypothesis test used when comparing two related samples, matched samples, or repeated measurements on a single sample to assess whether their population means ranks differ.

\subsection{Hasil Dan Pembahasan}

\subsubsection{Respondents Profiles}

Table1. Characteristics of Respondents based on Age, Education, Employment, Socio- Economy

\begin{tabular}{|l|l|l|c|c|}
\hline No & \multicolumn{2}{|c|}{ Characteristic } & $\begin{array}{c}\text { Numbers } \\
\text { N=41 }\end{array}$ & $\begin{array}{c}\text { Percentage } \\
(\mathbf{\%})\end{array}$ \\
\hline 1 & Ages & a. $<35$ & 2 & 4.9 \\
& (years) & b. $35-50$ & 12 & 29.3 \\
& $:$ & c. $51-60$ & 16 & 39.0 \\
& & d.> 60 & 11 & 26.8 \\
\hline 2 & Educat & a. Basic & 35 & 85.4 \\
& ions : & (Elementary/ & 6 & 14.6 \\
& & Secondary) & 0 & 0.0 \\
& & b.Junior High & & \\
& & c. University & & \\
\hline 3 & Jobs: & Unemployed & 23 & 56.1 \\
& & Employed & 18 & 43.9 \\
\hline 4 & Socio- & a. $\leq \quad$ Regional & 26 & 63.4 \\
& Econo & Minimum & 15 & 36.6 \\
& my & b. $>\quad$ Regional & & \\
& & Minimum & & \\
& & Wage & & \\
\hline
\end{tabular}

Table 1 shows that the age of the respondents is between 51-60 (39.0\%) the most and the least is $<35$ years old (4.9\%), the youngest is 26 years old and the oldest is 67 years old. The results of this study is similar to the study of Darnindro (2007) arguing that the highest risk for a person affected by cervical cancer was at the age of 40-45 years. Several studies show similarities such as research at Dr. Kariadi Hospital Semarang indicated that the incidence of cervical cancer was the highest at age 45-55 years (Wijayanti, 2007). Furthermore, research 
at Adam Malik Hospital in Medan mentioned that the incidence of cervical cancer was highest at the age of 35-55 years (Melva, 2008). Age is one factors that is considered to affect the prognosis of the patient and affects the immune system maturity in the body. At a young age to adulthood, immune capacity will peak and gradually decline, especially in later ages (Melva, 2008 and Wijayanti, 2007).

Respondents' education shows that most are in primary education (85.4\%) and secondary education (only senior high school) is $14.6 \%$. The results of this study in accordance with research of Susilawati (2013) that the education level of majority of respondents are in elementary school $(46.7 \%)$. A low level of education results in a lack of maternal knowledge in dealing with problems, while mothers with higher levels of education are generally welcome to accept changes or new things to maintain their health (Notoatmodjo, 2003).

$56.1 \%$ respondents do not work (as housewives) and those who are employed (43.9\%) mostly work as traders in the market. The results of this study are in line with previous studies which also showed that the majority of respondents $(50 \%)$ of cervical cancer patients are working as housewives (Susilawati, 2013).

The socioeconomic condition of the respondents show that more than half (63.4\%) whose income are below the minimum regional wage $(\mathrm{Rp}$ 1.350.000, approxiately USD 100) and $36.6 \%$ with income above minimum regional wage. The result of this research is similar to the research conducted by Mukharomah (2016) that some respondents have low income level.

\subsubsection{Level of Anxiety}

Table2. Level of Anxiety of Cervical Cancer Patients Before and After Palliative Care

\begin{tabular}{|l|c|c|c|c|c|}
\hline Anxiety & Lowest & Highest & Mean & SD & SE \\
\hline Pre tes & 19 & 36 & 27 & 3.94 & 0.62 \\
\hline Post test & 19 & 23 & 20 & 1.24 & 0.19 \\
\hline
\end{tabular}

Table2. shows that the anxiety level of cervical cancer patients before being given paliatif care, the average score is 27 and after being given paliatif care, the average score is 20 experiencing an average decrease of 7 points.

The anxiety level of cervical cancer patients following the chemotherapy program generally indicated no anxiety (40\%), mild anxiety (30\%), moderate anxiety $(20 \%)$, and severe anxiety
(10\%). From the data, there found 4 (four) important factors triggerring the anxiety of cervical cancer patients who follow chemotherapy program: a) cost, b) fear on the side effects of chemotherapy, c) being pessimistic that treatment is not successful, d) consideration / struggle for the family (Yolanda \& Karwur, 2013).

\subsubsection{Pap Smear Patients with Cervical Cancer Before and After Palliative Care}

The results of Pap smear examination of respondents before paliatif care conducted to all 41 respondents who suffered from cancer with stages varying from I, II, III, and after Palliative Care there are 7 respondents having negative pap smear (no malignancy) and 34 respondents in positive pap smear ( there is a ferocity).

One of the causes of declining immunity is the presence of stress that will weaken the immune response. In a state of stress or emotion such as anger and sadness, the hypothalamus which is the center of emotions will be aroused and then will stimulate the pituitary gland which then will stimulate the adrenal glands so that glucocorticoid hormones come out. The excessive hormone excess will result in antibodies and the inflammatory response decreases. The decline of this immune system facilitates the entry of cancer cells to attack the body, because the ability of these cells to recognize and fight the enemy can not function properly. It can be concluded that psychological stress affects the destruction of the ability of cell killing naturally for the destruction of tumor cells or cancer cells (Lubis, N.L. \& Hasnida. 2009).

\subsubsection{Effect of Palliative Care on Anxiety Levels and Pap Smears on Cervical Cancer Patients}

Table3. Effect of Palliative Care on Anxiety Levels

\begin{tabular}{|l|c|c|c|c|}
\hline Anxiety & Mean & SD & SE & P \\
\hline Pre- test & 27 & 3.94 & 0.62 & \\
\cline { 1 - 1 } $\begin{array}{l}\text { Post- } \\
\text { test }\end{array}$ & 20 & 1.24 & 0.19 & 0.000 \\
\hline
\end{tabular}

Based on Table 3, this study concludes that there is the positive influence of palliative care to decrease the anxiety level of cervical cancer patients $(\mathrm{p}=0.000)$. This study is in line with Susilawati (2013) that there is a strong relationship between family support and anxiety level of patients with palliative cervical cancer. Family coupling in the face of cervical cancer 
patients during chemotherapy is to seek social support, seek entertainment, seek information, control feelings, see the positive side of the problem, and spiritual support.

Anxiety is a common response after cancer is diagnosed. Based on interviews conducted by Utami \& Hasanat (1998), when they know that they have cancer, cancer patients will experience an unpleasant psychological condition, such as feeling shocked, anxious, fearful, confused, sad, panicked, anxious or feel alone, and overshadowed by death. Anxiety increases as individuals imagine a change in their life in the future as a result of illness or the consequences of the process of handling a disease. Sometimes the process of handling the cancer is very burdensome for patients than the disease itself, for example the process of radiation and drugs used to kill cancer cells can cause body damage even potentially to cause loss of body functions that can not be repaired. The process of handling cancer is also accompanied by pain, anxiety, sexual dysfunction, and the possibility of hospitalization for a long time (Lubis, NL \& Hasnida, 2009). Family support for cervical cancer patients who received chemotherapy is to give spirit, motivate, give advice, always take care of cancer patient, always accompany patient when treatment, and fulfill patient desire (Kharisma, 2014).

\section{CONClusion}

There is a decrease in anxiety levels before and after being given palliative care in patients with cervical cancer. There is a change of pap smear result in patients with cervical cancer before and after given palliative care. There is the effect of palliative care on the level of anxiety and pap smears in cervical cancer patients.

The importance of nurses to perform palliative care (psycho-education) by using psychoeducation guidelines that are easily applied in the field. Palliative care should be performed on cervical cancer patients because it can reduce anxiety and positive effect on the decrease of pap smear results.

\section{REFERENCES}

[1] Darnindro, N., Madeleine, R. J.\& Martina. 2007. Pengetahuan, Sikap, PerilakuPerempuan yang SudahMenikahMengenai Pap Smear
danFaktor-Faktoryang Berhubungan di RumahSusunKlender. Majalah Kedokteran Indonesia, Vol. 57, No. 7.

[2] Doyle, Hanks and MacDonald, 2003. Oxford Textbook of Palliative Medicine. Oxford Medical Publications (OUP) $3^{\text {rd }}$ ed.

[3] Hawari.(2001). Pendekatan Holistic pada Gangguan Jiwa Skizofrenia.FKUI: Jakarta

[4] Hayati. 2014. Gambaran tingkat kecemasan pasien kanker serviks stadium III di RSHS Bandung. FIK Universitas BSI Bandung. Jurnal ilmu keperawatan. Vol.II. No. 2 September 2014.

[5] KEPMENKES RI Nomor: 812/ MENKES/SK/ VII/2007 Tentang Kebijakan Perawatan Palliative. Menteri Kesehatan Republik Indonesia

[6] Lubis,N.L. \& Hasnida. 2009. Dukungan Sosial pada Pasien Kanker, Perlukah?. Terbitan Pertama. USU Press. Medan.

[7] Mukharomah, K.I.\& Cahyati, W. H. 2016. Hubungan faktor sosial ekonomi dengan keterlambatan diagnosis penderita kanker leher rahim di RSUD KOTA Semarang. Jurusan IKM Fakultas Ilmu Keolahragaan Universitas Negeri Semarang. Public Health Perspective Journal 1 (1) (2016).

[8] Melva. 2008. Faktor-faktor yang mempengaruhi kejadian kanker leher rahim pada penderita yang datang berobat di RSUP $\mathrm{H}$. Adam Malik Medan tahun 2008. Terdapat pada: Available from http://repository.usu. ac.id/ bitstream/123456789/6778/1/ 09E00801. pdf

[9] Notoatmodjo, S. (2003). Pengantar pendidikan kesehatan dan ilmu perilaku. Yogyakarta: Andi offset. Hal, 3-5.

[10] Stuart, G.W., Laraia, M.T. (2009). Principles and practice of Psychiatric Nursing. (7th ed). Philadelphia. Mosby.

[11] Susilawati, D. 2013. Hubungan antara dukungan keluarga dengan tingkat kecemasan penderita kanker serviks paliatif di RSUP DR Sardjito Yogyakarta. Departemen Keperawatan Maternitas Program Studi Ilmu Keperawatan, FK, Universitas Diponegoro. Jurnal keperawatan, Vol. 4, No. 2. Juli 2013. ISSN 2086-307 terdapat pada: http://ejournal.umm. ac.id/index.php/keperawatan/article/view/2358

[12] Wijayanti E. 2007. Perbandingan respons histopatologik dan klinik pasca terapi karsinoma serviks uteri tahun 2005-2006 berdasar karakteristik penderita. Semarang: Universitas Diponegoro. 
The Effect of Palliative Care toward the Level of Anxiety and Pap Smear among Cervical Cancer Patients

[13] Yolanda \&Karwur. 2013. Tingkat Kecemasan Pasien Kanker Serviks pada Golongan Ekonomi Rendah yang Mengikuti Program Universitas Kristen Satya Wacana Salatiga. Kemoterapi di RSUD Dr. Moewardi. FIKES Sains Medika. Vol. 5, No. 2. Juli - Desember $2013: 68-81$

Citation: Asrin, Siti Mulidah \& Welas Haryati, The Effect of Palliative Care toward the Level of Anxiety and Pap smear among Cervical Cancer Patients .ARC Journal of Public Health and Community Medicine. 2017; 2(2):19-23. doi:dx.doi.org/10.20431/2456-0596.0202003.

Copyright: (C) 2017 Authors. This is an open-access article distributed under the terms of the Creative Commons Attribution License, which permits unrestricted use, distribution, and reproduction in any medium, provided the original author and source are credited. 